\title{
La matière grasse du lait de dromadaire : composition, microstructure et polymorphisme. Une revue
}

\author{
Nadia KARRAY ${ }^{1}$ \\ Christelle LOPEZ ${ }^{2}$ \\ Michel OLLIVON ${ }^{3}$ \\ Hamadi ATTIA $^{1}$ \\ ${ }^{1}$ Unité d'analyse alimentaire, ENIS, \\ BPW 3038 Sfax, Tunisie \\ <karraynadia@yahoo.fr> \\ ${ }^{2}$ UMR 1253 Science et Technologie du Lait \\ et de I'Oeuf, INRA - Agrocampus, \\ Equipe Biochimie \& Physicochimie, \\ 65 rue de Saint-Brieuc. 35042 Rennes Cedex, \\ France \\ ${ }^{3}$ UMR 8612 du CNRS, Equipe Physico-Chimie \\ des Systèmes Polyphasés, 5 rue J.B. Clément, \\ 92296 Châtenay-Malabry, France
}

Article received on 20/04/2005

Accepted on 4/12/2005

\begin{abstract}
In camel milk, fat, that represents about 3.6\% of the composition, is dispersed in the form of globules, enveloped in a membrane, derived from the secreting cell and constituted by phospholipidprotein complexes.

This review examines the present state of knowledge of the dromedary milk fat. The topics dealt with are: composition (fatty acids and triacylglycerols), microstructure, fat globule size distribution and polymorphism (thermal and structural properties).
\end{abstract}

Key words: camel milk fat, fat globule, composition, MEB, DSC, X-ray diffraction

\section{Introduction}

The world camel population is estimated at several million animals. Dromedary rearing area is situated in the tropical and subtropical arid as well as semi-arid regions of Africa and Asia [1]. There are two different species of camels belonging to the camelus, namely, the dromedary camel (Camelus dromedarius; one-humped) and bactrian camel (Camelus Bactrianus; two-humped). Camels are known throughout history as companions of man in harsh desert environments [2]. It is widely admitted that dromedary camels produce more milk of high nutritional quality and for a larger period of time than other species in an environment that may be rightly termed as hostile in terms of extreme temperature, drought and lack of pasture [3].

The physical adaptations of this domestic animal were extensively investigated [4]. However, data about its milk are still scarce. The available data have been especially concerned with the general composition of the milk $[2,3,5-7]$ and its ability to transform into dairy products [8-11]. Thus, studies on its lipid components cause the interest of authors more and more.

Several authors have reported on the impossibility of its transformations into butter [12]. On the other hand, the feasibility of this inversion operation of this emulsion has been reported [13]. The very slow rate of spontaneous creaming $[14,15]$ and difficulty of centrifuge skimming have been shown [15-17]. The lipid content of lipid dromedary milk were the subject of many studies [6, 15, 18-23]. Recently, Karray et al. [17, 24] studied physical properties of dromedary milk fat.

The aim of this paper is to examine the present state of knowledge on the composition, the microstructure and essentially the physical properties of dromedary milk fat.

\section{Fatty acids composition}

In camel milk, fat, that represents about 3.6\% of the composition [6], is dispersed in the form of globules, enveloped in a membrane [15], derived from the secreting cell and constituted by phospholipid-protein complexes. Milk fat is mainly composed by triacylglycerols (TG) with a broad variety of Fatty Acids (FA) composition.

FA composition of camel milk fat varies as a function of the countries where camels live $[6,16,18$, $21,22,25]$. FA composition is influenced by environmental and physiological factors such as diet, stage of lactation and genetic differences within the species $[16,26]$ (table 1).

Various authors determined the FA composition of camel milk fat and compared it to that of bovine milk fat. Short-chain FA (C4-C12) are present in very small amounts in camel milk fat compared with the bovine milk fat $[15,16,18,21,22]$.

Depending on the authors and likely geographic area considered, the long chain saturated FA, of even-number (C14-C22) and odd-number (C15-C23) are higher for camel milk fat than those for 
Table 1. Fatty acid compositions (mole \%) of dromedary and bovine milk fats.

\begin{tabular}{|c|c|c|c|c|c|c|}
\hline \multirow{2}{*}{$\begin{array}{l}\text { Fatty acid } \\
\text { Carbon number }{ }^{2} \text { : } \\
\text { unsaturat. position }\end{array}$} & \multicolumn{5}{|c|}{ Dromedary $^{1}(\%)$} & \multirow{2}{*}{$\begin{array}{c}\text { Bovine (\%) } \\
\text { (d) }\end{array}$} \\
\hline & (a) & (b) & (c) & (d) & (e) & \\
\hline$C 4: 0$ & 0.1 & - & 1.10 & 0.60 & 0.02 & 2.6 \\
\hline C6:0 & 0.2 & - & 0.20 & 0.22 & 0.18 & 1.65 \\
\hline C8:0 & 0.2 & 0.1 & 1.10 & 0.21 & 0.18 & 1.12 \\
\hline $\mathrm{C} 10: 0$ & 0.2 & 0.12 & 0.20 & 0.25 & 0.32 & 2.75 \\
\hline $\mathrm{C} 12: 0$ & 0.9 & 0.77 & 0.80 & 1.19 & 0.92 & 3.89 \\
\hline $\mathrm{C} 14: 0$ & 11.4 & 10.14 & 9.70 & 13.11 & 10.84 & 13.05 \\
\hline $\mathrm{C} 14: 1 \omega 5$ & 1.6 & 1.86 & 0.80 & 0.70 & - & 1.7 \\
\hline C15:0 & 1.7 & 1.62 & 1.98 & 0.10 & - & 1.5 \\
\hline $\mathrm{C} 16: 0$ & 26.7 & 26.60 & 28.50 & 31.45 & 24.90 & 38.59 \\
\hline $\mathrm{C} 16: 1 \omega 7$ & 11.0 & 10.40 & 7.20 & 11.62 & 11.86 & 2.3 \\
\hline C17:0 & - & 1.21 & 1.10 & - & - & - \\
\hline C18:0 & 11.1 & 12.20 & 14.90 & 16.12 & 15.38 & 8.65 \\
\hline $\mathrm{C} 18: 1 \omega 9$ & 25.5 & 26.25 & 24.60 & 20.70 & 30.74 & 20.52 \\
\hline $\mathrm{C} 18: 2 \omega 6$ & 3.6 & 2.94 & 4.40 & 1.19 & 2.12 & 1.92 \\
\hline $\mathrm{C} 18: 3 \omega 3$ & 3.5 & 1.37 & 1.38 & 1.33 & 1.74 & 1.34 \\
\hline C19:0 & - & 0.57 & - & - & - & - \\
\hline $\mathrm{C} 20: 0$ & 0.6 & 0.57 & 1.38 & 0.49 & 0.66 & 0.49 \\
\hline $\mathrm{C} 21: 0$ & - & 0.38 & - & - & - & - \\
\hline C22:0 & - & 0.08 & - & - & - & - \\
\hline C22:1 & - & 0.57 & - & - & - & - \\
\hline Total $^{3}$ & 98.3 & 97.75 & 99.34 & 99.28 & 99.86 & 102.07 \\
\hline C4-C12 & 1.6 & 0.99 & 3.40 & 2.47 & 1.62 & 12.01 \\
\hline Uns / Sat & 0.85 & 0.80 & 0.63 & 0.56 & 0.86 & 0.37 \\
\hline
\end{tabular}

(a) from ref. [6] ; (b) from ref. [18] ; (c) from ref. [16] ; (d) from ref. [15] ; (e) from ref. [22].

${ }^{1}$ Molar percentage mean values of FA from: 5-10 individual camels (a), pooled sample of camel milk (b), 10 individual camels (c), 4 pooled milks (d) and individual animals (e).

${ }^{2}$ Experimental conditions are detailed in literature $[6,15,16,18,22]$.

${ }^{3}$ Data are reported as found in literature.

bovine milk fat $[6,18]$. Stearic acid (C18:0) is present in higher amount in camel milk fat $[15,18]$. The comparison of the amount of palmitic acid (C16:0) in camel and bovine milk fat is still discussed by the authors. Abu-Lehia [18] found that it is present in similar amounts in camel and bovine milk fat. However, Attia et al. [15] found that the proportion of C16:0 was lower in dromedary milk fat and Farah et al. [16] found that this fatty acid is present in higher quantities in camel milk originating from Kenya.

The content of unsaturated (C14-C18) FA is significantly higher in camel milk fat than that of bovine milk fat. The unsaturated FA of camel milk fat is characterized by a higher amount of the C16:1 FA as compared with bovine milk fat. It was found that oleic acid (C18:1), the more abundant unsaturated FA, is present in higher amount in camel milk fat [18] or that the proportion is practically the same in dromedary and bovine milk fat [15].

Gorban et Izzedine [21] studied the FA composition of TG by a new technique of ultroscan laser densitometry (table 2). Lipid components detected and fractionated by TLC techniques were transferred to a laser densitometric scanner. Ten plates were used, five plates for camel milk samples and five plates for lipid mixture standards (triacyglycerols,

Table 2. Summary of the structural and thermal characteristics of anhydrous dromedary milk fat observed by XRDT and DSC after cooling at different rates and melting at $1^{\circ} \mathrm{C} / \mathrm{min}$ [24].

\begin{tabular}{|c|c|c|c|c|c|c|}
\hline \multirow{2}{*}{$\begin{array}{l}\text { Cooling rate } \\
\left({ }^{\circ} \mathrm{C} / \mathrm{min}\right)\end{array}$} & \multirow{2}{*}{$\begin{array}{c}\text { Number of } \\
\text { crystallization } \\
\text { peaks }\end{array}$} & \multirow{2}{*}{$\begin{array}{c}\text { Initial } \\
\text { temperature of } \\
\text { crystallization } \\
\left({ }^{\circ} \mathrm{C}\right)\end{array}$} & \multirow{2}{*}{$\begin{array}{l}\text { Final melting } \\
\text { temperature } \\
\left({ }^{\circ} \mathrm{C}\right)\end{array}$} & \multicolumn{2}{|c|}{ Varieties observed on cooling } & \multirow{2}{*}{$\begin{array}{l}\text { Thermal behavior } \\
\text { on heating: } \\
\text { (Chain packing) }\end{array}$} \\
\hline & & & & Chain packing & Molecule stacking & \\
\hline 0.1 & 2 & 32 & 45.6 & $\beta^{\prime}$ & $2 \mathrm{~L}(42.15 \AA)$ & Only $\beta^{\prime}$ melts \\
\hline 1 & 3 & $\begin{array}{c}24 \\
20 \\
4\end{array}$ & 42.5 & $\alpha$ then $\beta^{\prime}$ & $\begin{array}{l}2 \mathrm{~L}_{1}(46.5 \AA) \\
2 \mathrm{~L}_{2}(42.15 \AA)\end{array}$ & $\begin{array}{l}\alpha \text { melts first } \\
\text { then } \beta^{\prime}\end{array}$ \\
\hline 5 & 2 & $\begin{array}{c}19.5 \\
6\end{array}$ & 43 & $\alpha$ then $\beta^{\prime}$ & $\begin{array}{l}2 \mathrm{~L}_{1}(47.6 \AA) \\
2 \mathrm{~L}_{2}(42.15 \AA)+ \\
4 \mathrm{~L}(84.5 \AA)\end{array}$ & $\begin{array}{l}\beta^{\prime} 4 \mathrm{~L} \rightarrow \beta^{\prime} 2 \mathrm{~L} \\
\text { and } \alpha \rightarrow \beta^{\prime} \\
\text { transition } \\
\text { then } \beta^{\prime} \text { melts }\end{array}$ \\
\hline
\end{tabular}


cholesterol ester, free cholesterol, monoacylglycerols, diacylglycerols, free fatty acids and phospholipids). $10.520 \mathrm{~cm}$ TLC plates of $0.25 \mathrm{~mm}$ thickness of silica gel were used. The retention time and percentage composition were determined. These authors were reported that the saturated FA of camel milk TG formed $66.1 \%$ of the total FA, similar to bovine milk fat (71.7 \%) [21]. Bovine milk TC have high content of short and medium-chain saturated FA. The main saturated FA in camel milk were $\mathrm{C} 16: 0$ (34.9 \%), C14:0 (14.5 \%) and C18:0 (9.7 \%). These FA are also the major saturated FA present in bovine milk TG, but a lesser extent than that of camel milk TG with $23.9 \%, 11.2 \%$ and $7.0 \%$ respectively. Short-chain FA (C4:0 - C8:0) are present only in bovine milk TG, but are notably absent in camel milk. Ruminants are capable of producing these FA by cellulose fermentation in the rumen, and thus camel milk is expected to contain these short FA. One possible explanation might be that these FA are rapidly metabolized by camel tissue before they have a chance to be excreted in the milk. The presence of medium-chain FA (C10:0-C14:0) in the milk of the bovine and camel could indicate their synthesis in the mammary gland.

The distribution of unsaturated FA in the triacyglycerols of camel milk is relatively important. Total polyunsaturated FA were higher in camel milk than bovine milk TG. This is a useful nutritional attribute since polyunsaturated FA may lower human serum lipids and hence lead to decrease the incidence of lipid-related cardiovascular diseases.

\section{Microstructure and fat globule size distribution}

Attia et al. [15] found that camel milk fat constitute a discontinuous phase similar to that of bovine milk and was made up of spherical dispersed droplets in the milk aqueous phase (figures 1 and 2). However, the microstructure of this emulsion revealed two particularities in comparison with that of bovine milk. The first was a higher frequency of smaller diameter globules (figure 3) which may lead to its more efficient hydrolytic cleavage by intestinal tract enzymes. Besides, it constitutes a major obstacle in butter technology since churning operation is much slower when fat globules are small [27]. Moreover, for cheese making, Mehaia [20] reported that more than $25 \%$ of camel milk fat were retained in the cheese whey, resulting in a lower cheese yield. This could be due to the small size of fat globules. Secondly, a more important membrane thickness is evident (figure 2); this property led to a better stability of camel

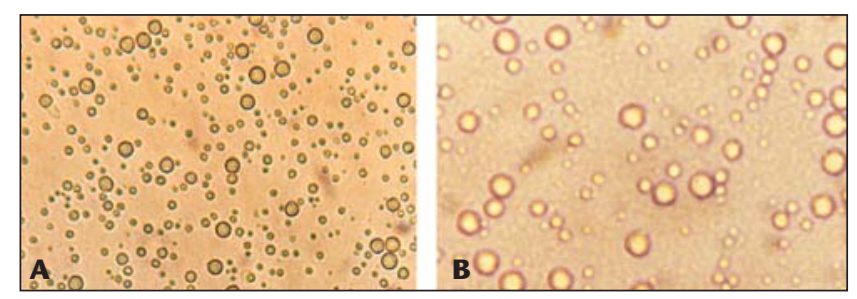

Figure 1. Fat globules of fresh dromedary milk (A) and bovine milk (B) as observed under a microscope [15].

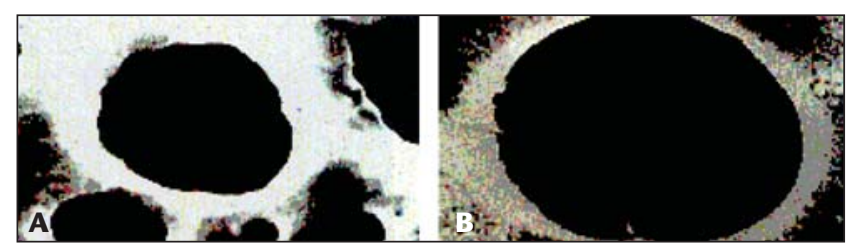

Figure 2. Fat globule structure of fresh dromedary milk (A) and bovine milk (B) (In clear: membrane) under scanning electron microscope [15].

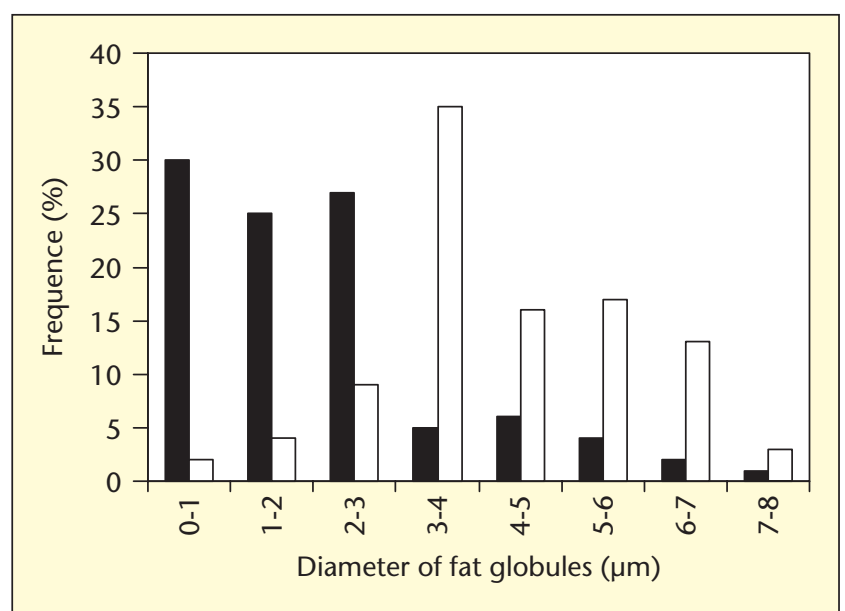

Figure 3. Size distribution of fat globules of dromedary milk (घ) and bovine milk ( $\square$ ) [15].

milk emulsion. In fact the study of the globule membrane composition of bovine milk showed a high amount of phospholipids [27]. This film, adsorbed at the fat globule surface, constitutes a real emulsifying agent for fat suspended in the milk.

It is the relatively high amount of this emulsifying and a relatively small size of fat globules which may explain the difficult creaming of camel milk. In fact, under identical centrifugation conditions $\left(25^{\circ} \mathrm{C}, 15 \mathrm{~min}\right.$, $3,000 \times g$ ), the total separation of bovine cream was obtained after only one centrifugation, while the dromedary skim milk was obtained after the third centrifugation $[15,17]$.

Information about the size and structure of milk fat globules is of interest from a biophysical, from a nutritional and technological point of view. The latter aspect is of increasing importance in milk separation as well as in butter and cheese making.

Mehaia [20] measured the size distribution of fat globules in camel milk using high light microscopy. The number, average diameters, surface and volume frequency functions were analysed and various parameters related to the stability of fat emulsion calculated by this author (table 3). He observed that up to $4.5 \mu \mathrm{m}$ diameter, the percentage of fat globules was $93.2 \%$ in camel and $81.5 \%$ in bovine milks. Besides, corresponding values of number average diameter and volume to surface average diameter were $2.70 \mu \mathrm{m}$ and $4.40 \mu \mathrm{m}$ for camel milk, and $3.60 \mu \mathrm{m}$ and $5.32 \mu \mathrm{m}$ for bovine milk. Moreover, Karray et al. [28] found that the mean diameter of fat globules in camel milk, measured by using laser light scattering, was $2.66 \mu \mathrm{m}$.

On the other hand, Mehaia [20] reported that the fat globules of camel milk exhibit the highest surface area of about $2.29 \mathrm{~m}^{2}$ for $1 \mathrm{mg}$ of fat,

Table 3. Important parameters of the fat globule-size distribution in camel and bovine milk [20].

\begin{tabular}{|lcc|}
\hline Parameter & $\begin{array}{c}\text { Camel } \\
\text { milk }\end{array}$ & $\begin{array}{c}\text { Bovine } \\
\text { milk }\end{array}$ \\
\hline Determined fat content $(\%)$ & 3.50 & 3.40 \\
Calculated fat content $(\%)$ & 3.41 & 3.41 \\
No. of globules $/ \mathrm{ml}$ milk & $3.5 \times 10^{9}$ & $1.5 \times 10^{9}$ \\
No. average diameter, $\mathrm{d}_{\mathrm{n}}(\mu \mathrm{m})$ & 2.70 & 3.60 \\
Volume average diameter, $\mathrm{d}_{\mathrm{v}}(\mu \mathrm{m})$ & 3.46 & 4.42 \\
Volume to surface average diameter, $\mathrm{d}_{\mathrm{vs}}(\mu \mathrm{m})$ & 4.40 & 5.32 \\
Surface area of fat $/ \mathrm{ml}$ of $\mathrm{milk}\left(\mathrm{m}^{2}\right)$ & 0.080 & 0.061 \\
Specific surface area of $1 \mathrm{~g}$ of fat $\left(\mathrm{m}^{-1}\right)$ & 0.222 & 0.073 \\
\hline
\end{tabular}


whereas the values for bovine milk were $1.79 \mathrm{~m}^{2}$. However, the specific area of globules per $1 \mathrm{~g}$ of fat follow the same tendency, being also the highest for camel and the lowest for bovine milk.

\section{Polymorphism}

As observed for other fats [29-37], X-ray diffraction (XRD) and differential scanning calorimetry (DSC) are the best techniques to characterize, respectively, the structural and thermal properties of ADMF $[17,24]$. Extensive descriptions of TG polymorphism based on data obtained using these techniques can be found in the literature [38, 39].

Briefly, XRD is an essential tool to identify the crystalline structures and polymorphism of pure TG and complex fats. Polymorphism results from the different possibilities of lateral packing of the FA chains and longitudinal stacking of molecules in lamellae. These two levels of organization are identifiable from the short and long spacings observed by XRD at wide and small angles, respectively, as detailed in [30].

The lateral packings of TC molecules frequently observed are $\alpha, \beta^{\prime}$ and $\beta$ in the order of their increasing stability. They have been related to different subcells that have been described in detail [40]. The longitudinal stackings of TG molecules correspond commonly to double or triple chain lengths ( $2 \mathrm{~L}$ or $3 \mathrm{~L})$. The long spacings, measured by XRD at smal angles, correspond to the repeat distance in the direction perpendicular to the lamellae.

DSC allows to characterize the thermal properties of pure TG and fats. The consequence of the complex TG composition of fats is that they do not have a true melting point but a broad melting range. The complex DSC recordings result from both the broad distribution of TC composition and the polymorphism of monotropic type of the TG [38]. The DSC recordings depend strongly on heating or cooling rates and on the entire thermal history of the sample [41].

ADMF has a broad melting range and the thermograms present more melting peaks than bovine ones, which is consistent with the differences in their FA compositions $[15,42]$. The final melting temperature and the thermal enthalpy are higher in dromedary milk fat, due to the very hot climate in which dromedaries live. Melting of the camel milk fat starts around $-26^{\circ} \mathrm{C}$ and is complete at about $43^{\circ} \mathrm{C}$ [42]. These characteristics are in relation with the relatively high concentration of long-chain FA that represent an important fraction of high melting point TG and a lower percentage of TC that melt in the medium range around $15^{\circ} \mathrm{C}$ [42]. XRD complements DSC for elucidating polymorphism of pure TG and fats. The coupling of XRD as a function of temperature (XRDT) and DSC was used to characterize the structural and thermal behaviors of pure TG $[43,44]$, fats $[30,32-34,36,37,44,45]$ and dispersed systems such as natural bovine milk fat globules $[29,31,34,36]$ and dromedary milk fat globules [46].

Camel milk fat is mainly composed by TC with a broad variety of FA composition. The complexity of its composition originates from the extreme diversity of its FA with respect to chain lengths, position and number of double bonds and branching. The second source of complexity of camel milk fat properties originates from its complex polymorphism. As observed for most of the lipids, each TG of ADMF can exhibit several crystalline forms. The existence of a polymorphism for each TC was studied by several authors $[38,39,47]$.

This polymorphism being mainly monotropic, rapidly-crystallized forms are metastable and the transitions between meastable and stable forms are irreversible. The occurrence of the different crystalline forms strongly depends on the thermal history of the TG.

Recently, Karray et al. $[17,24]$ by using coupling of DSC and XRDT, characterized the specific thermal and structural properties of ADMF. These authors examined the crystalline structures formed by TC of ADMF at slow $\left(0.1^{\circ} \mathrm{C} / \mathrm{min}\right)$, intermediate $\left({ }^{\circ} \mathrm{C} / \mathrm{min}\right)$ and fast $\left(5^{\circ} \mathrm{C} / \mathrm{min}\right)$ cool- ing rates and their evolution as a function of temperature during subsequent heating at $1{ }^{\circ} \mathrm{C} / \mathrm{min}$. A comparison of the structural and thermal properties of the crystalline species of ADMF formed as a function of the cooling rate was also undertaken.

For the first time, the crystalline structures formed by TC of ADMF were identified during a slow cooling $\left(0.1^{\circ} \mathrm{C} / \mathrm{min}\right)$ [17]. The lamellar organization of the TG molecules was characterized and detailed, as well as its thermal stability on heating. Unexpected, very simple structural behavior, characterized by XRD at small angles, was associated with complex thermal properties. Indeed, a single crystalline form corresponding to a $2 \mathrm{~L}(42.15 \AA)$ stacking and a chain packing of $\beta^{\prime}$ type is observed on cooling (figures $4 A$ and $4 B$ ). The DSC recording obtained simultaneously with small and wide angle XRD experiments during cooling of ADMF at $0.1{ }^{\circ} \mathrm{C} / \mathrm{min}$ revealed the existence of up to 6 exotherms on slow cooling (figure 5A). A similar complex behavior was also observed on subsequent heating (figure $5 B$ ). Upon heating, the melting DSC curve represents about the reverse process of that of crystallization with again the progressive solubilization in the melt of this single crystalline form (figure 6). The existence of a single species is confirmed by all the temperature analysis of the XRD data obtained during both crystallization and melting processes. Moreover, from the absence of any new line at small and wide angles during heating there is no evidence of any $\beta^{\prime} \rightarrow \beta$ transition. Karray et al. [24] showed that cooling of ADMF in fast conditions $\left(5^{\circ} \mathrm{C} / \mathrm{min}\right)$, or at intermediate cooling rate $\left(1^{\circ} \mathrm{C} / \mathrm{min}\right)$, first leads to the crystallization of $\alpha$ form with the existence of longitudinal stacking of the TG molecules corresponding to double chain length structures $(47.6 \AA$ and $46.9 \AA$, respectively, likely the same structure with slightly different TG compositions) (figure $7 A$ ). This lateral organization of FA chains in hexagonal cell has not been observed on slow cooling at $0.1{ }^{\circ} \mathrm{C} / \mathrm{min}$ that directly generates the stable $\beta^{\prime}$ form $2 \mathrm{~L}(42.15 \AA$ ) (figure $7 A)$. This unstable crystalline $\alpha$ form is responsible for the occurrence of a single line at $4.16 \AA$ at wide angles on the plot recorded on cooling at $1{ }^{\circ} \mathrm{C} / \mathrm{min}$ and the observation of a $4.15 \AA$ line on the plot recorded on cooling at $5{ }^{\circ} \mathrm{C} / \mathrm{min}$ (figure $7 \mathrm{~B}$ ). This small distance was absent on the plot recorded on cooling at $0.1{ }^{\circ} \mathrm{C} / \mathrm{min}$ at wide angles. Indeed, there are only those that correspond to the coexistence of two $\beta^{\prime}$ forms ( $3.86 \AA, 4.15 \AA, 4.29 \AA$ and $4.4 \AA$ peaks) (figure $7 B$ ). At this cooling rate, the ADMF doesn't seem to be able to crystallize under a $\beta$ form (which is the alternate case for fats not crystallizing under a $\beta^{\prime}$ form [22]) probably because of its complex and heterogeneous TG composition that makes difficult the adoption of a compact structure like that of $\beta$ form. Furthermore, it is of interest to note that a weak XRD bump corresponding to the formation of a new variety with a thickness of $84.5 \AA$ is recorded during cooling of ADMF at $5^{\circ} \mathrm{C} / \mathrm{min}$. This structure has not been observed on cooling previously neither at the slow cooling of $0.1^{\circ} \mathrm{C} / \mathrm{min}$ [17] nor at that of $1^{\circ} \mathrm{C} / \mathrm{min}$ [24]. Moreover, such crystalline structure $4 \mathrm{~L}$ have never been met in the anhydrous bovine milk fat when it is cooled at different rates [30, 32, 36]. Taking into account the difference in composition in FA and necessarily in TG between the milks of this two species, this is not at all surprising. Then, this should be considered as a characteristic of dromedary milk fat. Karray et al. [24] proposed the possible molecular packing within the unit cell of the different polymorphic forms reported above, figure 8 summarizes some possible models of arrangement that might explain the $\mathrm{X}$-ray data observed, especially the presence of a line at $84.5 \AA$.

DSC recordings show that the shape of both the crystallization and melting curves depend on the cooling rate. Table 3 summarizes the different thermal properties of the ADMF after cooling at different rates and its subsequent melting at $1{ }^{\circ} \mathrm{C} / \mathrm{min}$. It is clear that the initial temperature of crystallization of ADMF decreases with increasing cooling rate, in relation with the nucleation process [39]. 


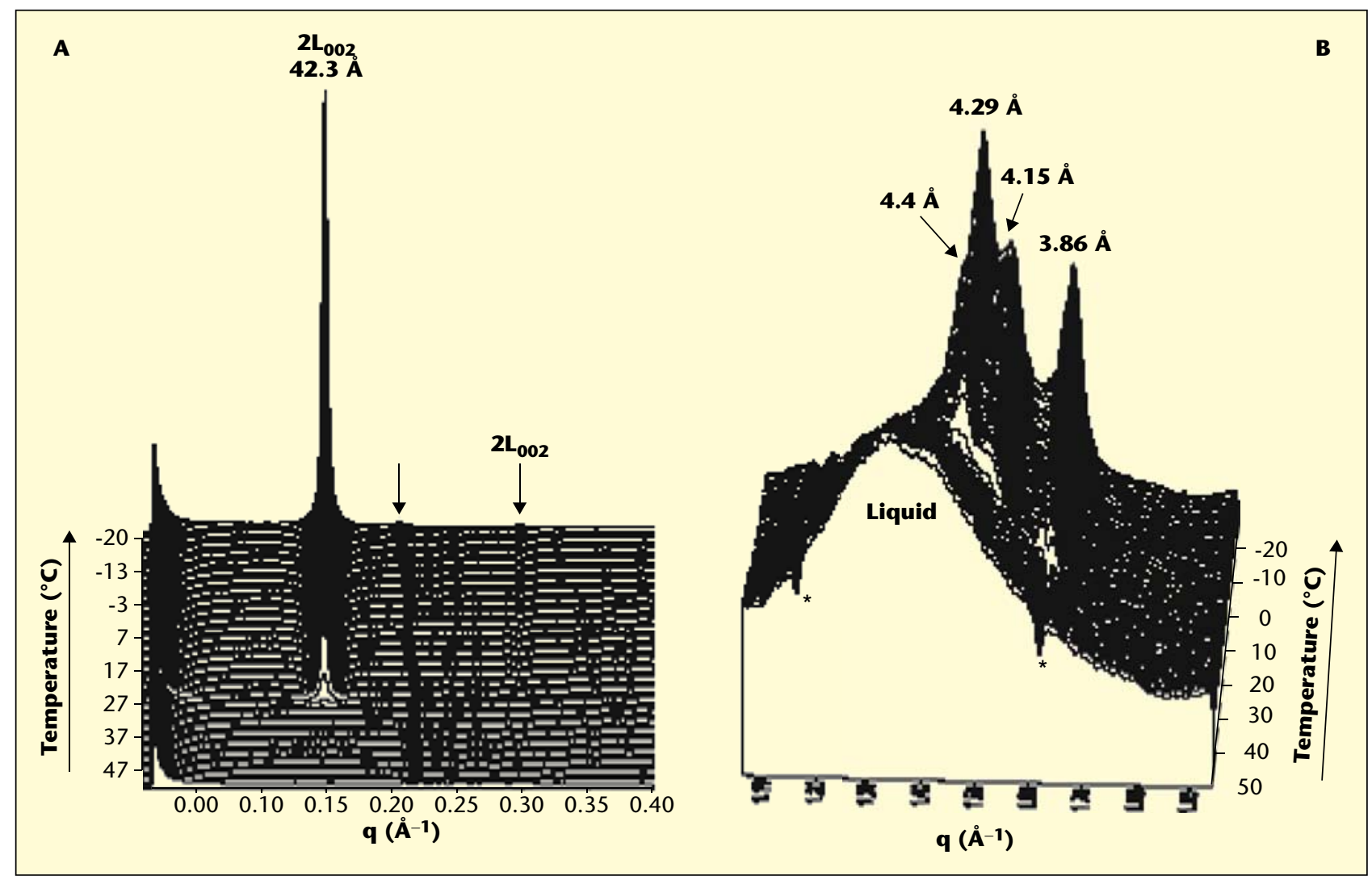

Figure 4. Three dimensional plots of small (A) and wide (B) angle X-ray diffraction patterns recorded as a function of time during cooling of anhydrous dromedary milk fat from $60^{\circ} \mathrm{C}$ to $-20^{\circ} \mathrm{C}$ at $0.1^{\circ} \mathrm{C} / \mathrm{min}$ using coupled XRDT-DSC* [17].

* Experiments were conducted using Microcalix (CNRS, Châtenay-Malabry, France), installed on the D22 line $(\lambda=1.5498 \AA)$ of DCI synchrotron of LURE (Laboratoire pour I'utilisation du rayonnement électromagnétique, Orsay, France) as previously described [30].
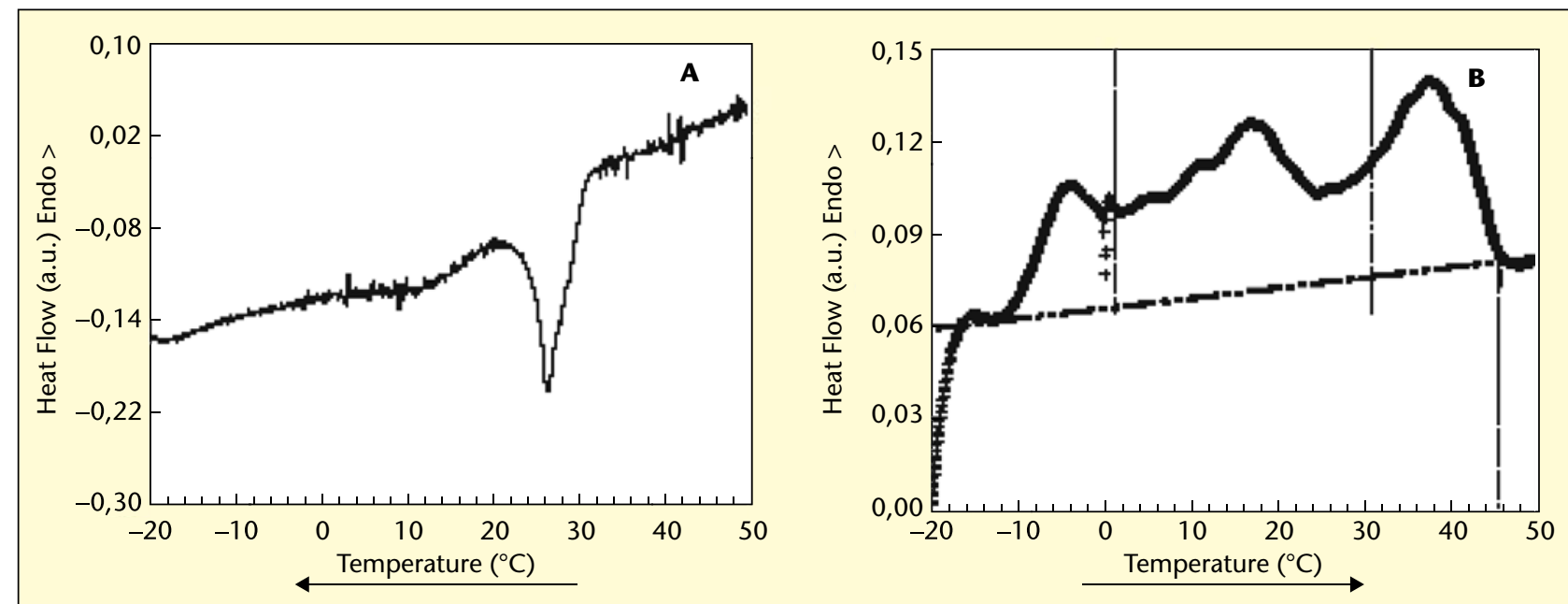

Figure 5. (A) DSC crystallization curve recorded simultaneously to XRD experiments during cooling of anhydrous dromedary milk fat at $0.1^{\circ} \mathrm{C} / \mathrm{min}$, (B) DSC melting curve recorded simultaneously to XRD experiments during heating of anhydrous dromedary milk fat from $-20^{\circ} \mathrm{C}$ to $60^{\circ} \mathrm{C}$ at $1{ }^{\circ} \mathrm{C} / \mathrm{min}$, following cooling at $0.1^{\circ} \mathrm{C} /$ min $[17]$. 


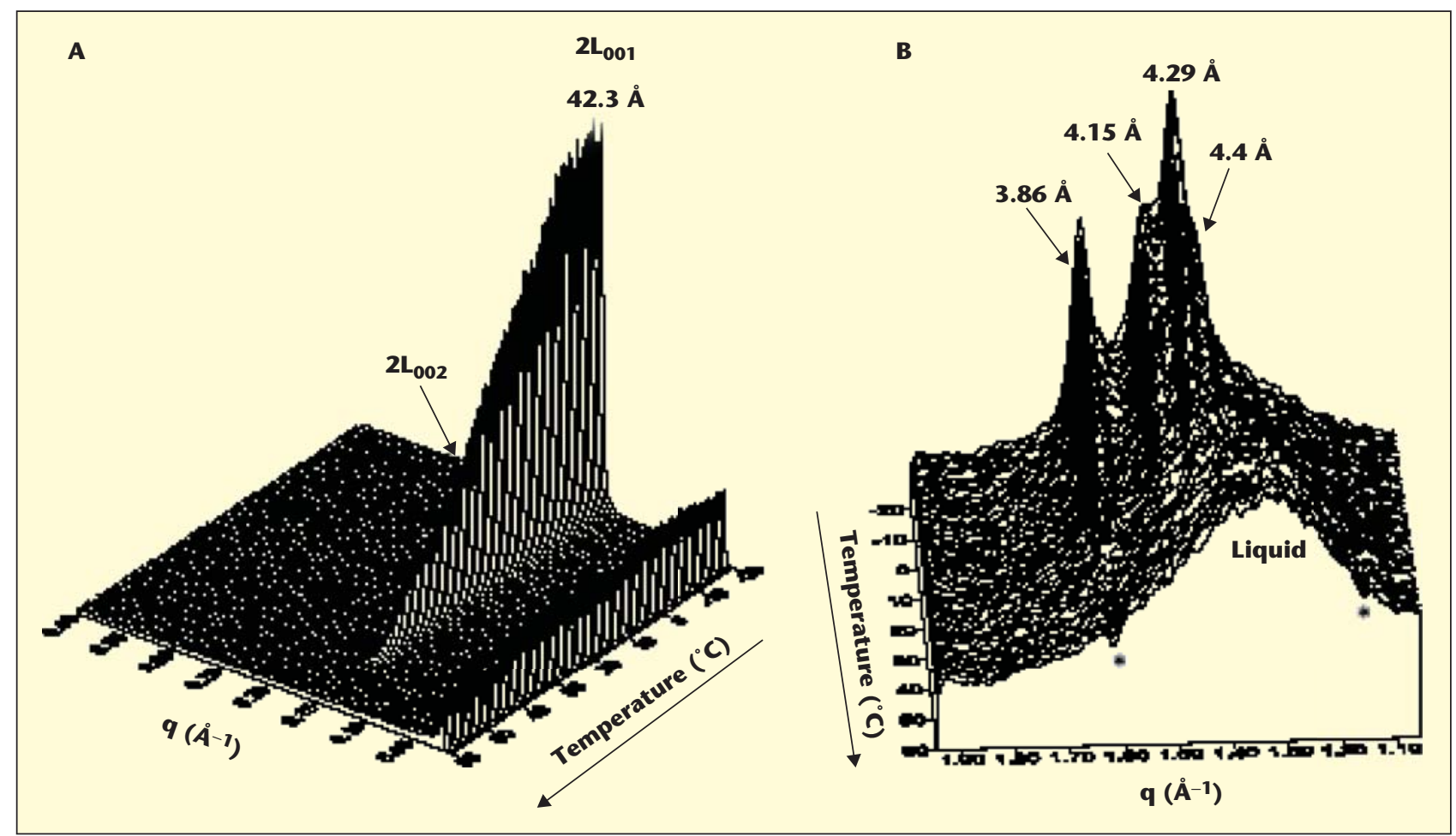

Figure 6. Three-dimensional plots of small- (A) and wide- (B) angle X-ray diffraction patterns recorded as a function of time during heating of anhydrous dromedary milk fat from $-20^{\circ} \mathrm{C}$ to $60^{\circ} \mathrm{C}$ at $1^{\circ} \mathrm{C} / \mathrm{min}$ after cooling at $0.1^{\circ} \mathrm{C} / \mathrm{min}[17]$.
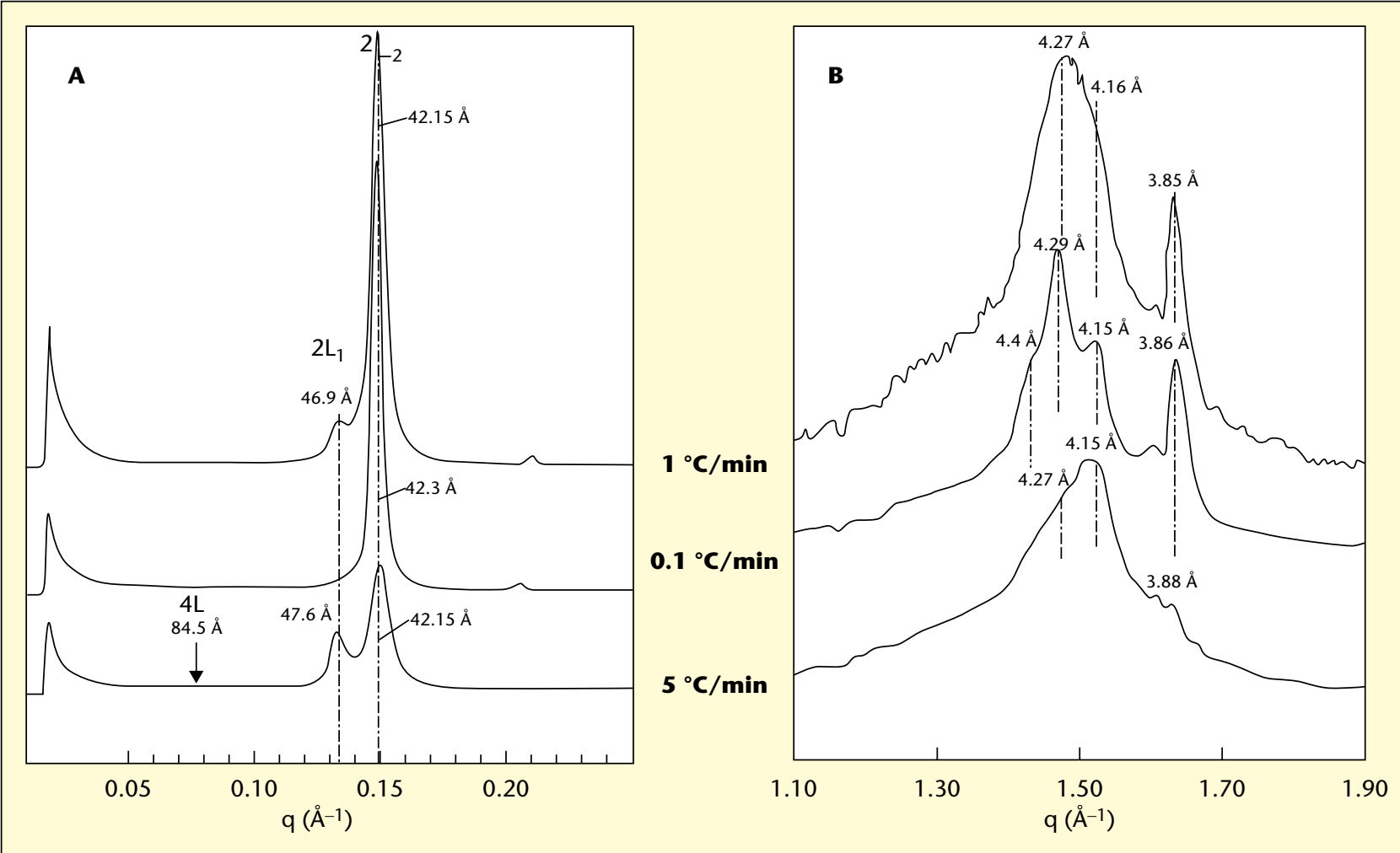

Figure 7. XRD patterns recorded at $-20^{\circ} \mathrm{C}$ at (A) small and (B) wide angles after different cooling of anhydrous dromedary milk fat at different rates as indicated on the figure [24]. 


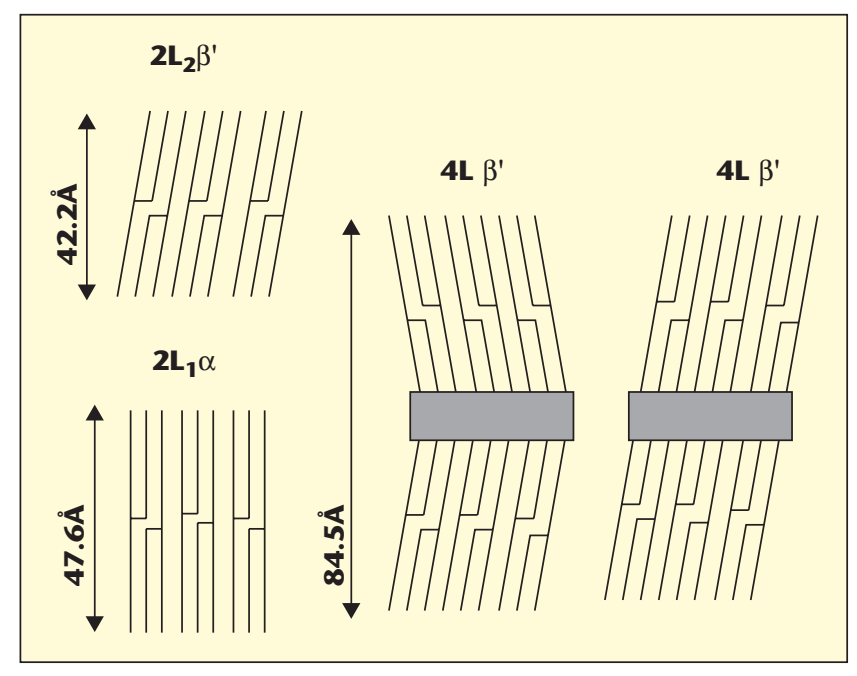

Figure 8. Possible stackings of triglyceride molecules in the crystalline forms reported above. Angle of tilt of chains in the $\beta^{\prime}$ forms is about $27.7^{\circ}$ assuming that $\alpha$ form is untilted $\left(0^{\circ}\right)$. Greyed zone corresponds to end of chain packing disorder [24].

\section{REFERENCES}

1. RICHARD D. MODES D'ÉLEVAGE. In: Richard D, ed. Le dromadaire et son élevage. France: IEMVT, Maison Alfort, 1985.

2. MERIN U, BERNSTEIN C, VAN CREVELD CN, YAGIL R, GOLLOP N. Came (Camelus dromedarius) colostrum and milk composition during the lactation. Milchwissenschaft 2001; 56: 70-3.

3. KHAN BB, IQBAL A. Production and composition of camel milk Review. Pak J Agri Sci 2001; 38: 64-8.

4. YAGIL R, ETZION T. Effect of drought condition on the quality of camel milk. J Dairy Res 1980; 47: 159.

5. KNOESS KH. The camel as a meat and milk animal World. Anim Rev 1977; 22: 39.

6. SAWAYA WN, KHALIL JK, AL-SHALHAT A, AL-MOHAMMED H. Chemical composition and nutrition quality of camel milk. J Food Sci 1984; 49: 744-7.

7. BAYOUMI S. Studies on composition and rennet coagulation of camel milk. Kiel Milchwirtsch Forschungsber 1990; 42: 3-8.

8. MOHAMED MA, LARSSON-RAZNIKIEWICZ M, MOHAMUD MA. Hard cheese making from camel milk. Milchwissenschaft 1990; 45: 716-8.

9. MEHAIA MA. Fresh soft white cheese from camel milk: composition, yield and sensory evaluation. J Dairy Sci 1993; 76: 2845-55.

10. ABU-TARBOUSH HM. Comparison of associative growth and proteolytic activity of yogurt starters in whole milk from camels and cows. I Dairy Sci 1996; 79: 366-71.

11. INAYAT S, ARAIN MA, KHASKHELI M, MALIK AH. tudy of the effect of processing on the chemical quality of soft unripened cheese made from camel milk. Pak / nutr 2003; 2: 102-5.

12. DICKSON HRP. The Arab of the desert. London: George Allan and Unwin ed Ltd, 1951; (409).

13. KNOESS KH, MAKHDUM AJ, RAFIQ M, HAFEEZ M. Potentiel laitier de la chamelle. Rev Mond Zootech 1986; 57: 11.

14. FARAH Z, RÜEGG MW. The creaming properties and size distribution of fat globules in camel milk. J Dairy Sci 1991; 74: 2901-4.

15. ATTIA H, KHEROUATOU N, FAKHFAKH N, KHORCHANI T, TRIGUI N. Dromedary milk fat: biochemical, microscopic and rheological characteristics. I Food Lipids 2000; 7: 95-112.
16. FARAH Z, STREIFF T, BACHMANN MR. anufacture and characterization of camel milk butter. Milchwissenschaft 1989; 44: 412-4.

17. KARRAY N, LOPEZ C, LESIEUR P, OLLIVON M. Dromedary milk fat: thermal and structural properties 1. Crystalline forms obtained by slow cooling. Lait 2004; 84: 399-416.

18. ABU-LEHIA IH. Physical and chemical characteristics of camel milk fat and its fractions. Food Chem 1989; 34: 261-71.

19. FARAH Z. Composition and characteristics of camel milk. J Dairy Res 1993; 60: 603-26.

20. MEHAIA MA. The fat globule size distribution in camel, goat, ewe and cow milk. Milchwissenschaft 1995; 50: 260-3.

21. GORBAN MS, IZZELDIN M. Fatty acids and lipids of camel milk and colostrum. In J Food SC Nut 2001; 52: 283-7.

22. CARDAK AD, YESTISMEYEN A, BRUCKNER $H$. Quantitative comparison of camel, goat and cow milk fatty acids. Milchwissenschaft 2003; 58: 34-6.

23. CARDAK AD, YESTISMEYEN A, BRUCKNER H. Quantitative comparison of free fatty acids in camel, goat and cow milk. Milchwissenschaft 2003; 58: 127-30.

24. KARRAY N, LOPEZ C, LESIEUR P, OLLIVON M. Dromedary milk fat: thermal and structural properties. 2. Influence of cooling rate. Lait 2005; 85: 433-51.

25. ORLOV VK, SERVETNIK-CHALAYA GK. Some physical and chemical characteristics of fat and fatty acid composition of lipids of camel milk. Voprosy Pitaniya 1981: 567-9.

26. PALMQUIST DL, BEAULIEU AD, BARBANO DM. Feed and animal factors influencing milk fat composition. J Dairy Sci 1993; 76: 1753-71.

27. ALAIS C. Les bactéries lactiques. Les levains. In: Science du lait. Principes des techniques laitières. Paris: Sepaic, 1984: 345-88.

28. KARRAY LN, ATTIA H. La matière grasse du lait camelin: connaissances actuelles. Microbio Hyg Ali 2004; 16: 11-8.

29. LOPEZ C, LESIEUR P, KELLER G, OLLIVON M. Thermal and structural behavior of milk fat. 1. Unstable species of cream. / Coll Int Sci 2000; 229: 62-71.

30. LOPEZ C, LAVIGNE F, LESIEUR P, BOURGAUX C, OLLIVON M. Thermal and structural behavior of milk Fat. 1. Unstable species of anhydrous milk fat. I Dairy Sci 2001; 84: 756-66.

31. LOPEZ C, LESIEUR P, BOURGAUX C, KELLER G, OLLIVON M. Thermal and structural behavior of milk fat. 2. Crystalline forms obtained by slow cooling of cream. / Coll Int Sci 2001; 240: 150-61.

32. LOPEZ C, LAVIGNE F, LESIEUR P, KELLER G, OLLIVON M. Thermal and structural behavior of anhydrous milk Fat. 2. Crystalline forms obtained by slow cooling. J Dairy Sci 2001; 84: 2402-12.

33. LOPEZ C, RIAUBLANC A, LESIEUR P, BOURGAUX C, KELLER G, OLLIVON M. Definition of a model fat for crystallization-in-emulsion studies. I Am Oil Chem Soc 2001; 78: 1233-44.

34. LOPEZ C, BOURGAUX C, LESIEUR P, OLLIVON M. Crystalline structures formed in cream and anhydrous milk fat at $4{ }^{\circ} \mathrm{C}$. Lait $2002 ; 82: 317-35$.

35. LOPEZ C, BOURGAUX C, LESIEUR P, BERNADOU S, KELLER G, OLLIVON M. Thermal and structural behavior of milk fat: 3 . Influence of cooling rate and droplet size on cream crystallization. / Coll Int Sci 2002; 254: 64-78.

36. LOPEZ C, LAVIGNE F, LESIEUR P, OLLIVON M. Thermal and structural behaviour of anhydrous milk fat: 3. Influence of cooling rate. J Dairy Sci 2005; 88: $511-26$.

37. SATO K. Polymorphism of pure triacylglycerols and natural fats. In: Advances in Applied Lipid Research, vol. 2. JAI Press, Inc., 1996: 213-68.

38. HAGEMANN JW. Thermal behavior and polymorphism of acylglycerides. In: Garti N, Sato K, eds. Crystallisation and polymorphism of fats and fatty acids. New-York: Marcel Dekker Inc., 1988: 9-95. 
39. OLLIVON M, PERRON R. Propriétés physiques des corps gras. In: Karleskind A, Wolff JP, Guttmann JF, eds. Manuel des corps gras. Paris: Lavoisier, 1992: 433-42.

40. LARSSON K. In: Lipids-Molecular organization, physical functions and technical applications. The Oily Press, 7, 1994.

41. OlLIVON M, PERRON R. In: Hollo J, ed. Fat science, Part A. New York: Elsevier, 1985: 107-16.

42. RÜEGG MW, FARAH Z. Melting curves of camel milk fat. Milchwissenschaft 1991; 46: 361-2.

43. KELLENS M, MEEUSSEN W, RIKEL C, REYNAERS H. Time-resolved X-ray diffraction studies of the polymorphic behaviour of tripalmitin using synchrotron radiation. Chem Phys Lipids 1999; 52: 79-98.
44. LAVIGNE F. Polymorphisme et transitions de phases des triglycérides. Applications aux propriétés thermiques et structurales de la matière grasse laitière anhydre et de ses fractions. Ph. D. Univ. Paris VII, Paris XI et ENSIA, 1995.

45. LOISEL C, KELLER G, LECQ G, BOURGAUX C, OLLIVON M. Phase transition and polymorphism of cocoa butter. J Am Oil Chem Soc 1998; 75: 425-39.

46. LOPEZ C, KARRAY N, LESIEUR P, OLLIVON M. Crystallisation and melting properties of dromedary milk fat globules studied by $\mathrm{X}$-ray diffraction and differential scanning calorimetry. Comparison with anhydrous dromedary milk fat. Eur J Lipid Sci Technol 2005; 107: 673-83.

47. SMALL DM. In: Hanahan DJ, ed. The physical chemistry of lipids. From alkanes to phospholipids. New York: Handbook of lipid Research, Plenum Press, 1986: 347-82. 